\title{
CORRESPONDENCE
}

\section{Basic research: goddess and cow}

Many of the painful choices faced by Vannevar Bush in shaping US science policy after the Second World War (Nature 466, 922-923; 2010) still confront those who formulate federal funding for research today.

The polymath Johann Wolfgang von Goethe once said of science: "To one man it is the highest thing, a heavenly goddess; to another it is a productive and proficient cow, who supplies them with butter." But if the goddess is forgotten, will the cow starve?

Attempts to save the cow based on the financial demands of scientific organizations are not enough today - times are tough for everyone. And remembering the goddess by defending intellectual curiosity runs the risk of insulating a sandbox of scholars from grown-up evaluations of the quality or public relevance of work financed by taxpayers.

The justification for both curiosity-driven and missionoriented research in the future will rest on a deeper rethinking of goals and process. This may be feasible using ideas emerging from a thriving programme at the US National Science Foundation, based on what previous presidential science adviser Jack Marburger called a "science of science policy". Past returns on investments should be documented thoroughly to help set priorities and estimates of outcomes more persuasively.

But critical, non-quantitative judgements will continue: reviewers must use intuition as well as analysis to sort out new ideas, and funding agencies must impose stern standards of quality. Even in wartime, that is what Vannevar Bush did.

In short, honour the goddess and feed the cow.

Rodney W. Nichols New York City, USA,

rod.nichols@verizon.net

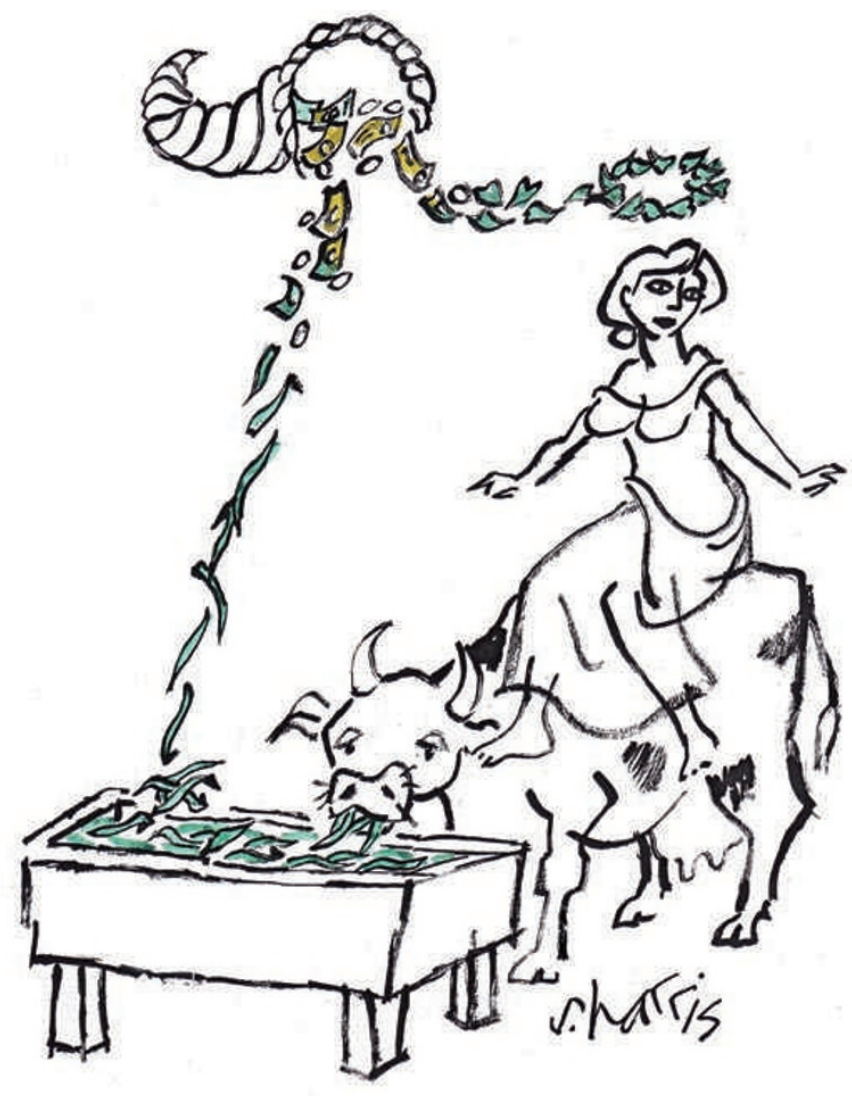

\section{Basic research: bizarre but essential}

Using terminology that tries to satisfy political masters as well as the research endeavour can be risky (Nature 466, 922-923; 2010). Part of the reduction in usage of the term 'basic research' is probably due to the emergence of 'translational research', which puts new knowledge to practical use. As a result, basic scientists have popularized the term 'discovery research'. But all types of research are important.

Research is a pipeline for ideas that occasionally sprout into useful applications for generating wealth, which in turn helps to support more investment in discovery. This process has been examined to death but is unpredictable by its very nature. All we can do is ensure that the best quality is achieved at every level, and that we do not inadvertently limit the resources and ideas of those who practise this bizarre but essential driver of progress.

Jim Woodgett Samuel Lunenfeld Research Institute, Toronto,

Canada,

woodgett@lunenfeld.ca

\section{Stimulus funds are being well spent}

I agree that the denigration by US Republican senators Tom Coburn (Oklahoma) and John McCain (Arizona) of some of the research projects funded by last year's economic-stimulus package is "ill-informed and wide of the mark” (Nature 466, 797; 2010).

Their report is not their first on the subject; last December they targeted some other research funded through the rigorous peer-review process of the National Science Foundation (NSF). Number 35 in that report is a grant I received to continue my 37-year study of how the changing environment is affecting the phenology and abundance of flowering of more than 100 species of montane wild flowers.

It took two attempts for my research proposal to be accepted, at a time when only about $10 \%$ of proposals were successful. I can't speak for all the agencies that funded studies using stimulus money, but I am confident from my experience that NSF funds are being well spent.

I offered to talk with both senators about my work and why it is an appropriate, cost-efficient way to stimulate research activity and the economy; they did not respond. Their efforts to make light of serious research follow in the footsteps of the Golden Fleece Awards, established in 1975 by former senator William Proxmire, which many recipients of federal funding paradoxically came to consider as a highlight of their research careers.

David W. Inouye University of Maryland, USA, inouye@umd.edu

\section{Middle East talks must include water}

The current round of PalestinianIsraeli negotiations should confront the region's water conflict described in Haim Watzman's book review (Nature 466, 820; 2010). The conflict has persisted in a covert form since the 1995 Oslo II Agreement; to right the agreement's wrongs, water must be distributed according to fair and legal principles.

Central to the present conflict is the fact that Oslo II sealed the inequitable distribution and control of the transboundary River Jordan and groundwater flows. Nine out of every ten drops 